\title{
UNIVERSITY OF PENNSYLVANIA RADIOCARBON DATES XIV
}

\section{BARBARA LAWN}

Department of Physics and University Museum, University of Pennsylvania, Philadelphia, Pennsylvania 19104

This date list includes those series of samples completed in this laboratory as of December 1970. The B.P. ages are based upon A.D. 1950, and are calculated with a half-life value of $5568 \mathrm{yr}$. All samples were counted at least twice for periods of not less than 1000 minutes each. Errors quoted are derived from measurement of samples, background, and modern-age calibration, but do not include any half-life error. All samples were pretreated with $3 \mathrm{~N} \mathrm{HCl}$, and some, where noted, were given additional pretreatment with $2 \% \mathrm{NaOH}$ for the removal of possible humic contaminants.

Standard calibration samples are 126-yr-old oak samples which, when corrected for age, have $\mathrm{C}^{14}$ contents equal to $95 \%$ of the NBS oxalic acid standard. The $\mathrm{C}^{13}$ relationship between the Oak standard and NBS limestone standard \#20 is $-25.7 \pm 1.3 \%$ as measured on the University of Pennsylvania mass spectrograph. Where $\delta \mathrm{C}^{13}$ is reported (cf. P-1621 and $\mathrm{P}-1544)$ and the results accordingly corrected for isotopic fractionation, the $\mathrm{C}^{13}$ relationship has been measured with respect to the Oak standard.

I wish to thank John Hedrick for his careful work in the processing of these samples.

\section{SAMPLE DESCRIPTIONS}

\section{ARCHAEOLOGIC SAMPLES \\ A. Yugoslavia}

\section{P-1598. Lepinski Vir}

$6814 \pm 69$ 4864 B.c.

Charcoal from hearth construction of House 32, belonging to later phase of proto-neolithic settlement (L.V. Id), at Lepinski Vir, on right bank of Danube $14.5 \mathrm{~km}$ up river from Donje Milanovac, Yugoslavia $\left(44^{\circ}\right.$ $31^{\prime} \mathrm{N}$ Lat, $22^{\circ} 2^{\prime} \mathrm{E}$ Long). Site is noteable for its trapezoidal house floors in the proto-Neolithic levels, stratified beneath typical Starcevo remains. Coll. and subm. 1969 by D. Srejovic, Univ. of Belgrade, Archaeol. Inst., Belgrade, Yugoslavia. For additional dates from this site, see BM-379, $6900 \pm 150$ (R., 1969, v. 11, p. 292; Srejovic, 1968a, 1968b, 1969; Nandris, 1968).

\section{Kyrenia Wreck series}

\section{B. Greece}

Kyrenia Wreck lies in $90 \mathrm{ft}$ of water off $\mathrm{N}$ coast of Cyprus, Greece, $1.6 \mathrm{~km}$ from port of Kyrenia ( $35^{\circ} 20^{\prime} \mathrm{N}$ Lat, $33^{\circ} 20^{\prime} \mathrm{E}$ Long). This wreck is earliest known example of sheathing hull in lead to keep shipworms from eating into planking. Samples coll. and subm. 1969 by M. L. Katzev, Univ. Mus., Univ. of Pennsylvania (1969, 1970a, 1970b). 


\section{P-1621. Almonds}

$$
\begin{array}{r}
2124 \pm 60 \\
174 \text { в.c. } \\
\delta C^{13}=-6.48 \% \%
\end{array}
$$

Almonds found in 12 different amphoras of the last 3rd of the 4th century B.c.

\section{P-1622. Wood from hull of ship}

\section{Franchthi Cave series}

Franchthi Cave ( $37^{\circ} 26^{\prime} \mathrm{N}$ Lat, $23^{\circ} 8^{\prime}$ E Long) is near $\mathrm{W}$ tip of high, rugged headland, directly across bay from village of Koilada near Porto Cheli in S Argolid, Peloponnese, Greece. Site is especially important because of its apparently continuous stratigraphic sequence from late Palaeolithic through Mesolithic and the critical transition to Neolithic. There are no stratified prehistoric remains beyond the Late Neolithic. Samples coll. 1967, 1968, and 1969 during joint excavations by Indiana Univ. and Univ. Mus., Univ. of Pennsylvania; subm. by T. W. Jacobsen and M. H. Jameson, Univ. Mus., Univ. of Pennsylvania (Jacobsen, 1968, 1969 a, 1969b, 1969c).

\section{P-1658. Area F/A, Unit 10}

\section{A.D. 1845}

$105 \pm 44$

Charcoal mixed with earth from hearth in Area F/A, Unit 10, ca. 0.60 to $0.75 \mathrm{~m}$ below modern surface. Coll. 1969. Date expected to be very recent. Comment: $\mathrm{NaOH}$ pretreatment.

\section{P-1663. Pit H-1, Unit 22}

Charcoal, earth, and some splintered wood from hearth belonging to Pit H-1, Unit 22, ca. $2.0 \mathrm{~m}$ below modern surface. Coll. 1969. Date expected to be recent. Comment: $\mathrm{NaOH}$ pretreatment.

\section{P.1659. Area F/A, Unit 39}

$5163 \pm 78$ 3213 B.C.

Charcoal mixed with earth from Area F/A, Unit 39, ca. 1.25 to $1.55 \mathrm{~m}$ below modern surface. Coll. 1969. Date expected to be very Late Neolithic. Comment: $\mathrm{NaOH}$ pretreatment.

\section{P-1660. F/A Balk, Unit 72 S}

Charcoal mixed with earth from F/A Balk, Unit $72 \mathrm{~S}$, ca. 1.87 to $1.95 \mathrm{~m}$ below modern surface. Coll. 1969. Date expected to be Late Neolithic. Comment: NaOH pretreatment.

\section{P-1630. F/A Balk, Unit 89 N}

$6110 \pm 86$

Charcoal mixed with earth from F/A Balk, Unit $89 \mathrm{~N}$, ca. 2.24 to $2.30 \mathrm{~m}$ below modern surface. Coll. 1969. Date expected to be Late Neolithic. Comment: $\mathrm{NaOH}$ pretreatment. 
Charcoal mixed with earth from F/A Balk, Unit $97 \mathrm{~N}$, ca. 2.35 to $2.40 \mathrm{~m}$ below modern surface. Coll. 1969. Date expected to be Late Neolithic. Comment: $\mathrm{NaOH}$ pretreatment.

\section{P.1662. F/A Balk, Unit 114 N}

$6691 \pm 81$ 4741 в.c.

Charcoal mixed with earth from F/A Balk, Unit 114, ca. 2.75 to $2.80 \mathrm{~m}$ below modern surface. Coll. 1969. Date expected to be early Late or late Middle Neolithic. Comment: $\mathrm{NaOH}$ pretreatment.

\section{P.1537. Pit G-1, Unit 11}

$6646 \pm 79$

\section{P.1537. 4696 B.c.} Crom Pit G-1, Unit 11, ca. 2.80/3.36 to $2.80 / 3.60 \mathrm{~m}$ below modern surface. Coll. 1968. Date expected to be Middle Neolithic. Comment: $\mathrm{NaOH}$ pretreatment.

\section{P-1399. Pit A, Unit 56}

$7194 \pm 112$

5244 B.c.

Charcoal mixed with earth from Pit A, Unit 56, ca. 3.95/4.02 to $4.07 / 4.15 \mathrm{~m}$ below modern surface. Coll. 1967. Date expected to be very early Middle Neolithic. Comment: $\mathrm{NaOH}$ pretreatment.

\section{P.1667. Pit H, Unit 37 Y}

Charcoal mixed with earth from Pit $\mathrm{H}$, Unit $37 \mathrm{Y}$, ca. $3.75 \mathrm{~m}$ below modern surface. Coll. 1969. Date expected to be Early Neolithic. Comment: $\mathrm{NaOH}$ pretreatment.

\section{P.1525. Pit F/F-1, Unit 42 B 1}

$7704 \pm 81$ 5754 в.c.

Charcoal mixed with earth from Pit F/F-1, Unit 42 B 1, ca. 4.03/4.16 to $4.07 / 4.21 \mathrm{~m}$ below modern surface. Coll. 1968. Date expected to be Early Neolithic.

\section{P-1392. Pit A, Unit 63}

$7794 \pm 140$

Charcoal mixed with earth from Pit A, Unit 63 Coll 1967. Date expected to be Aceramic Neolithic. Comment: $\mathrm{NaOH}$ pretreatment.

\section{P-1398. Pit G, Unit 31}

$$
9098 \pm 139
$$

Charcoal mixed with earth from Pit $G$, Unit $31, c^{2}$. 4 ( $4.63 / 4.94 \mathrm{~m}$ below mo lithic. Comment: $\mathrm{NaOH}$ pretreatment.

\section{P-1536. Pit G-1, Unit 22}

Ciharcoal mixed with earth from Pit G-1, Unit 22, ca. 4.12/4.60 to $4.39 / 4.83 \mathrm{~m}$ below modern surface. Coll. 1968. Date expected to be Mesolithic. Comment: $\mathrm{NaOH}$ pretreatment. 


\section{P.1527. Pit F/F-1, Unit 44 B 5}

Charcoal mixed with earth from Pit F/F-1, Unit 44 B 5, ca. 4.43/ 4.47 to $4.58 / 4.60 \mathrm{~m}$ below modern surface. Coll. 1968. Date expected to be late Mesolithic. Comment: $\mathrm{NaOH}$ pretreatment.

\section{P-1526. Pit F/F-1, Unit 43 A 1}

$8022 \pm 76$

Charcoal mixed with earth from Pit F/F-1, Unit 43 A 1, ca. 4.64/4.66 to $4.77 / 4.83 \mathrm{~m}$ below modern surface. Coll. 1968. Date expected to be late Mesolithic. Comment: $\mathrm{NaOH}$ pretreatment.

\section{P-1664. Pit H-1, Unit A 101}

$8941 \pm 117$ 6991 B.C.

Charcoal mixed with earth from Pit H-1, Unit A 101, ca. 4.23 to $4.30 \mathrm{~m}$ below modern surface. Coll. 1969. Date expected to be Mesolithic. Comment: $\mathrm{NaOH}$ pretreatment.

\section{P-1665. Pit H-1, Unit A 117 P}

$9477 \pm 134$ 7527 B.C.

Charcoal mixed with earth from Pit H-1, Unit A 117 P, ca. $4.50 \mathrm{~m}$ below modern surface. Coll. 1969, using normal colln. procedures (cf. P-1666). Date expected to be Mesolithic. Comment: $\mathrm{NaOH}$ pretreatment.

\section{P-1666. Pit H-1, Unit A 117 R}

$8742 \pm 114$

Charcoal from Pit H-1, Unit A 117 R, ca. 4.50 m below modern surface. Coll. 1969, using a water-sieving procedure on the fill removed from this unit. Date expected to be comparable to P-1665. Comment: $\mathrm{NaOH}$ pretreatment.

\section{P-1517. Pit G-1, Unit 39}

$9034 \pm 108$

Charcoal mixed with earth from Pit G-1, Unit 39, ca. 6.06/6.28 to 6.20/6.43 m below modern surface. Coll. 1968. Date expected to be Mesolithic. Comment: $\mathrm{NaOH}$ pretreatment.

\section{P-1518. Pit G-1, Unit 46}

$8938 \pm 100$

6988 B.C.

Charcoal mixed with earth from Pit G-1, Unit 46, ca. 6.41/6.69 to 6.47/6.74 m below modern surface. Coll. 1968. Date expected to be Mesolithic. Comment: $\mathrm{NaOH}$ pretreatment.

\section{P-1518-A. Pit G-1, Unit 46}

Portion of same sample as P-1518, but did not receive any pretreatment for removal of possible humic contaminants.

\section{P-1519. Pit G/G-1, Unit 60}

$9264 \pm 144$ 7314 B.c.

Charcoal mixed with earth from Pit G/G-1, Unit 60, ca. 7.35/7.68 to 7.35/7.70 m below modern surface. Coll. 1968. Date expected to be early Mesolithic. Comment: $\mathrm{NaOH}$ pretreatment. 


\section{P.1522. Pit H, Unit 61 B 1}

$9298 \pm 130$

7348 B.c.

Charcoal mixed with earth from Pit H, Unit $61 \mathrm{~B} \mathrm{1,} \mathrm{ca.} \mathrm{4.85/5.07} \mathrm{to}$ $4.90 / 5.14 \mathrm{~m}$ below modern surface. Coll. 1968. Date expected to be early Mesolithic. Comment: $\mathrm{NaOH}$ pretreatment.

\section{P.1668. Pit H, Unit 71 B 2-3}

$11,930 \pm 168$

Charcoal mixed with earth from Pit $\mathrm{H}$, Unit $71 \mathrm{~B} 2-3$, ca. $6.65 \mathrm{~m}$ below modern surface. Coll. 1969. Date expected to be roughly comparable to P-1520 (cf.).

\section{P-1520. Pit H, Unit 59 A 1}

$11,093 \pm 260$

Charcoal mixed with earth from Pit $\mathrm{H}$, Unit $59 \mathrm{~A} \mathrm{1}$, ca. 7.10 to $7.15 \mathrm{~m}$ below modern surface. Coll. 1968. Sample from Pleistocene level. Comment: this sample when processed, was not large enough for our counters, therefore, it was sent to Isotopes for counting (I-4219).

\section{P.1397. Halieis}

$5102 \pm 72$

3152 B.c.

Sea shells including Murex trunculus, Cerithium vulgatum, and Cardium edule, assoc. with Late Neolithic pottery from pit in bedrock on acropolis at Porto Cheli (ancient Halieis) in S Argolid, Peloponnese, Greece $\left(37^{\circ} 19^{\prime} \mathrm{N}\right.$ Lat, $23^{\circ} 8^{\prime} \mathrm{E}$ Long). Sample coll. 1962 by C. K. Williams; subm. by M. H. Jameson. Comment (T. W. Jacobsen): even though this is a shell sample, resulting date seems to coincide nicely with its archaeol. context.

\section{Lorenzo Kiln series}

Lorenzo Kiln is $4 \mathrm{~km}$ from Porto Cheli in Peloponnese, S Argolid, Greece ( $37^{\circ} 17^{\prime} \mathrm{N}$ Lat, $23^{\circ} 10^{\prime} \mathrm{E}$ Long). Kiln was submerged in sea water at edge of bay and appears to have been suddenly abandoned after a firing, possibly due to inundation by the sea, to an earthquake, or both. Well-preserved charred brush was found in both stoking chambers. Overlying charcoal was extremely fine-textured blue sea clay, ca. $30 \mathrm{~cm}$ thickness, showing varve-like layering with no shells, stones, or coarse sand. Above the blue clay was sand and gravel layer. Kiln was thought to have been used from Late Roman to Mediaeval times.

\section{P.1427. Stoking Chamber A}

$137 \pm 43$

Charcoal from Stoking Chamber A, 50 to $60 \mathrm{~cm} \mathrm{~S}$ of G-8, midway between chamber walls, 60 to $73 \mathrm{~cm}$ below water level. Comment: $\mathrm{NaOH}$ pretreatment.

\section{P.1428. Stoking Chamber B}

$115 \pm 43$

Charcoal from Stoking Chamber B, $8 \mathrm{~m}$ grid line, midway between chamber walls, 54 to $65 \mathrm{~cm}$ below water level. Comment: $\mathrm{NaOH}$ pretreatment. 


\section{Korucu Tepe series}

$$
\text { C. Turkey }
$$

Korucu Tepe is a medium-size mound in the Altimova plain $\mathrm{E}$ of Elazig, Turkey (38 $42^{\prime} \mathrm{N}$ Lat, $39^{\circ} 30^{\prime} \mathrm{E}$ Long), at elev. ca. $+824 \mathrm{~m}$; coll. 1968 and 1969 by joint expedition, Univ. of Chicago, California (Los Angeles) and Amsterdam; subm. by Maurits van Loon, Oriental Inst., Univ. of Chicago (van Loon and Buccellati, 1969; Mellink, 1969, 1970).

P-1626. Operation H, Area 6, Level 5B

Charcoal, Sample KRC S-370, in and around a crushed pot under Stone Pile $\mathrm{M}$ in early Iron age room, coll. by S. Winn. Tentatively dated ca. 1000 to 800 B.c. and represents a non-Hittite culture of unknown affiliation. Comment: $\mathrm{NaOH}$ pretreatment.

\section{P.1611. Operation O 21 NW, Level 2c}

Charcoal, Sample KRC 68-S112, from Op. O 21 N W, Level 2c, coll. by G. Buccellati, from terminal Hittite Empire levels consisting mainly of pits and dumping areas, one of which yielded 12 clay sealings with impressions of hieroglyphic stamp seals, proving that the area was under Hittite adm. (cf. P-1612). Comment (M.v.L.): MASCA corrected new half-life dates for P-1611, 1162 в.C. and P-1612, 1108 в.C. from terminal Hittite Empire levels are only ones that fit historical data for Hittite Empire, which must have come to an end between 1200 and 1150 B.c., perhaps 1189 в.c. when invading "sea peoples" clashed with Egypt. Even uncorrected new half-life dates remain far below expectations from historical sources.

\section{P.1612. Operation O 21 NW, Level 2d}

$$
2871 \pm 63
$$$$
921 \text { B.C. }
$$

Charcoal, Sample KRC 68-S113, from Op. O 21 NW, Level 2d, coll. by G. Buccellati (cf. P-1611). Comment: $\mathrm{NaOH}$ pretreatment.

\section{P-1613. Operation V 12, Level 8}

Charcoal, Sample KRC 68-S278, coll. by E. Griffin, from between Walls I and IV from major building at $\mathrm{E}$ foot of mound, with walls $1.5 \mathrm{~m}$ thick, which had burned and toppled sideways and are contemporary with city wall (cf. P-1614, P-1615, and P-1616).

\section{P.1614. Operation V $12 \mathrm{~W}$, Level 8}

Charcoal, Sample KRC 68-S225, coll. by E. Griffin (cf. P-1613, 1627, 1615, and 1616). Comment: $\mathrm{NaOH}$ pretreatment. Large tolerance due to undersized sample, $86.60 \%$ normal pressure.

P-1627. Operation U 12, Area 1, Level 9

Charcoal (probably wood from building), Sample KRC 69-S78, 
coll. by B. B. Williams from burned debris on ash floor of corridor at time of destruction of "burned building." Comments: $\mathrm{NaOH}$ pretreatment. (M.v.L.): work in 1969 showed that "burned building" was actually passage through city wall, flanked by a tower.

\section{P.1615. Operation O 23, Area 2, Level 4}

$3244 \pm 59$

Charcoal, Sample KRC 68-S110, coll by R Magnus. Wheelmarked light gray pottery, perhaps continuing same tradition (cf. P-1617 and -1618), was used with Hittite red burnished and cream-slipped wares when town was surrounded by 2 parallel stone foundations packed with loam, which once must have carried a mud brick fortification $5.30 \mathrm{~m}$ wide. Sample should date levels built soon after construction of city wall, perhaps ca. 1600 в.c. Comment: $\mathrm{NaOH}$ pretreatment.

\section{P-1616. Operation O 24 E, Level 8}

$3247 \pm 63$

Charcoal, sample KRC 68-S68, coll. by E. Griffin (cf. P-1615).

\section{P-1628. Operation N 11, Area 4, Level 4 \\ $3989 \pm 63$}

Grarred wheat (Triticum aestivum) id. by W. van Zeist, Univ. of Groningen, Netherlands, Sample KRC 69-S100, coll. by R. I. Christensen from burned floor, containing smashed storage and cooking vessels, within partly walled area with large hearth. Building thought to be 26th to 23rd century в.c. Sample should date destruction which put an end to early Bronze Age II occupation.

\section{P-1629. Operation N 11, Area 3, Level 7}

$3963 \pm 65$

Charred wheat (Triticum aestizum), id. by W. van Zeist, Sample KRC $68-S 451 / 452$, coll. by D. J. W. Meijer, from burned material on floor of 26th to 23rd century B.c. establishment, preceding burned early Bronze Age II house and should date earlier establishment.

\section{P-1617. Operation O 11, Area 1, Level 5}

$4084 \pm 53$

Charcoal, Sample KRC 69-S107, coll. by J. Zarins, should date occupation of Korucu Tepe by "Khirbet Kerak" people (cf. P-1618). Comment: half of sample (P-1617-A, $4106 \pm 65)$ received usual 3N HCl pretreatment, other half (P-1617-B, $4074 \pm 64$ ) was given additional $2 \%$ $\mathrm{NaOH}$ pretreatment; difference is not significant, and average of both portions is quoted here.

\section{P-1618. Operation O 10, Area 1, Level 15}

$4224 \pm 62$ 2274 B.C.

Charcoal, Sample KRC 69-S109, coll. by D. Barbolla, should date occupation of Korucu Tepe by "Khirbet Kerak" people (cf. P-1617).

\section{Aphrodisias series}

Aphrodisias, Turkey (37 $43^{\prime} \mathrm{N}$ Lat, $28^{\circ} 48^{\prime}$ E Long) is ca. $153 \mathrm{~km}$ $\mathrm{SE}$ of present port of Izmir or $129 \mathrm{~km} \mathrm{E}$ of ancient port of Miletus. All 
samples are from "Acropolis" mound at Aphrodisias, which lies within much larger area enclosed by Hellenistic/ Roman walls of later classical city. Depths in Trenches 3 to 5 are measured from a subdatum point, $13.86 \mathrm{~m}$ above zero datum for entire classical site. Subdatum in Trench 7 is $16.34 \mathrm{~m}$ above zero datum. Levels from top are as follows: A-4, A-3, A-2 and A-1, Late Bronze age; A, B', B, C, and D, Middle Bronze age; E, I, II, III, and IV, Early Bronze age III. Samples coll. 1967-1969; subm. by Barbara Kadish, New York Univ., New York (1969).

\section{P-1644. Trench 7, Unit 580}

$3440 \pm 69$

Wood charcoal from beam lying between opening through stones of Wall L, Trench 7, Level A-1, Unit 580, at depth $-3.79 \mathrm{~m}$. Coll. 1969. Comment: $\mathrm{NaOH}$ pretreatment. Charcoal contained small rootlets, sample chosen to be free of rootlets as possible (cf. P-1656).

\section{P-1656. Trench 7, Unit 580}

$3587 \pm 82$

1637 B.c.

Portion of Sample P-1644 that received rootlet pretreatment as per Haynes (1966; see discussion, Lowdon et al., 1970). Comment: result from pretreated sample seems reasonable, i.e., slightly older than hand-sorted sample.

\section{P-1645. Trench 5, Unit 464}

$3339 \pm 62$

Wood charcoal from floor of Complex B. Coll. 1968. Comment: $\mathrm{NaOH}$ pretreatment.

\section{P.1646. Trench 5, Unit 487}

$\mathbf{3 4 1 4} \pm 69$

Wood charcoal from upper part of Complex C, or possible temporary occupation on top of debris of C. Coll. 1968.

\section{P.1647. Trench 5, Unit 494}

$3673 \pm 73$

1723 в.c.

Wood charcoal from lowest extent of Complex C, at depth $-4.44 \mathrm{~m}$. Coll. 1968. Comment: $\mathrm{NaOH}$ pretreatment.

\section{P.1648. Trench 3, Stratum 7A}

$3543 \pm 61$ 1593 в.c.

Wood charcoal above burned debris of Complex II, separated from it by small deposit of brown earth at depth $-5.76 \mathrm{~m}$. Charcoal probably assoc. with Complex I. Coll. 1967. Comment: $\mathrm{NaOH}$ pretreatment.

P-1649. Trench 3, Unit 224

$3561 \pm 55$

1611 B.c.

Charred seeds from Pithos II, Rm. 1, Structure A, of Complex II. Seeds appeared at depth $-6.81 \mathrm{~m}$ inside pithos and continued without earth intervening to bottom of pithos. Coll. 1967. 
P.1650. Trench 3, Unit 227

$3715 \pm 59$

1765 B.C.

Charred seeds from Pithos I, Rm. 1, Structure A, of Complex II, at depth -6.80 to $7.10 \mathrm{~m}$. Coll. 1967.

P-1651. Trench 3, Unit 221

$3858 \pm 64$ depth --7.15 m. Coll. 1967.

P-1652. Trench 4, Unit 343

$3987 \pm 61$

Wood charcoal from Structure B, at base of Complex II floor, at depth --6.94 m. Coll. 1968.

\section{P-1653. Trench 3, Unit 267}

$3624 \pm 55$

1674 B.C.

Wood charcoal from floor level of Structure B, Complex IV, at depth -7.83 m. Coll. 1967. Comment: $\mathrm{NaOH}$ pretreatment.

\section{P-1654. Trench 4, Unit 348}

$3943 \pm 86$

Wood charcoal from surface of destruction debris of Complex IV, at depth --7.39 m. Coll. 1968. Comment: $\mathrm{NaOH}$ pretreatment.

\section{P-1655. Pekmez Trench}

$2249 \pm 59$

299 B.C.

Combined small charcoal sample from Level 7, Pekmez Mound, Trench 2. Comparison of material from both mounds led excavators to believe that Levels 5 to 8 of Pekmez Trench 2 are from earlier period than levels so far excavated on Acropolis mound; however, this combined sample does not seem to confirm this.

\section{P-1434. Alaca Huyuk, Level 11-12}

$4285 \pm 62$

Charcoal from Level 11-12 (4th level of Chatcolithic) at Alaca Huyuk, near town of Alaca $\left(40^{\circ} 10^{\prime} \mathrm{N}\right.$ Lat, $34^{\circ} 52^{\prime} \mathrm{E}$ Long) in N Turkey. Coll. 1966 by H. Z. Kosay; Ethnog. Mus., Ankara, Turkey; subm. 1966 by M. J. Mellink (Kosay and Akok, 1966; Arik, 1937). For additional dates from Alaca Huyuk see P-824, $3744 \pm 61$; P-825, $2540 \pm$ 50; and P-826, $4200 \pm 58$ (R., 1965, v. 7, p. 191).

\section{Acem Hoyuk series}

Acem Höyük ( $38^{\circ} 30^{\prime} \mathrm{N}$ Lat, $33^{\circ} 55^{\prime} \mathrm{E}$ Long) is a large Bronze age mound NW of Aksaray in central Turkey. Samples coll. by Nimet Özgüc, Univ. of Ankara; subm. by M. J. Mellink (Özgüc, 1968).

P-1555. Charred beam

$3611 \pm 49$

1661 B.c.

Part of wooden beam in charred condition was part of large palace destroyed by fire. 
P-1595. Charred crab apples (?)

Charred crab apples (?) from jar on floor of magazine in large burnt palace.

\section{Other countries}

\section{P-1623. Hotu Cave, Iran}

$10,731 \pm 269$

8781 B.C.

Charcoal and soil from gray black earth under red Gravel 2 in D trench of Hotu Cave ( $36^{\circ} 20^{\prime} \mathrm{N}$ Lat, $\left.53^{\circ} 35^{\prime} \mathrm{E} \mathrm{Long}\right) 7 \mathrm{~km} \mathrm{~W}$ of Behshahr and $7 \mathrm{~km} \mathrm{~S}$ of present shoreline just $\mathrm{E}$ of modern village of Turujan, Iran. Sample coll. 1951 and subm. 1969 by C. S. Coon, Gloucester, Mass. Comment: $\mathrm{NaOH}$ pretreatment. For additional date from this level see P-39, 11,860 \pm 840 (Ralph, 1955). P-1623 was dated because P-39 was from early solid carbon counting days and not pretreated for removal of possible humic contamination. P-1623 was processed at Univ. of Pennsylvania Radiocarbon Lab., but was too small for our counters, therefore, counted by Isotopes (I-4635).

\section{P-1633. Nuk, Alaska}

$2284 \pm 56$

334 B.c.

Charcoal from single habitation level of Pit House 1 , Nuk $\left(65^{\circ} \mathrm{N}\right.$ Lat, $165^{\circ} \mathrm{W}$ Long), $29 \mathrm{~km} \mathrm{E}$ of Nome, Alaska. Coll. 1969 by J. R. Bockstoce and subm. by F. G. Rainey, Univ. Mus., Univ. of Pennsylvania, Philadelphia.

\section{P-1544. Puerco Indian Ruin, Arizona}

$726 \pm 45$

A.D. 1224

$C^{13}=+14 \%$

Charred corn from Puerco Indian Ruin, Petrified Forest Natl. Park, Apache Co., Arizona ( $34^{\circ} 51^{\prime} \mathrm{N}$ Lat, $109^{\circ} 55^{\prime} \mathrm{W}$ Long), from $0.30 \mathrm{~m}$ deep layer of trash in intimate assoc. with roof material. Assoc. pottery types from previous excavations (Shroeder, 1961) indicate site occupied for span of not more than $100 \mathrm{yr}$ from A.D. 1250 to 1350 .

\section{P-1625. El Tigre, Mexico}

$1670 \pm 49$

Wood (Bucida) id. by B. F. Kukachka, Forest Products Lab., U. S. Dept. of Agri., Madison, Wisconsin, from test pit, sealed beneath excavated ridges of field, $27 \mathrm{~m}$ from $\mathrm{N}$ bank of Rio Candelaria, across from modern colony of El Tigre, Campeche, Mexico (18 $7^{\prime} \mathrm{N}$ Lat, $90^{\circ} 48^{\prime \prime} \mathrm{W}$ Long) and nearby Classic archaeol. ruins which may be Itzamkanac, "capital" of Maya prov. of Acalan. Coll. and subm. 1969 by D. E. Puleston, Univ. of Minnesota. Comments: $\mathrm{NaOH}$ pretreatment. (D.E.P.): date introduces possibility that Chinampa-type ridged fields may be much earlier in this area than expected. Very limited ceramic data suggest major occupation of nearby archaeol. ruins in classic times which fits very closely to sample date (Andrews, 1943; Scholes and Roys, 1948). 


\section{Marcavalle series, Peru}

Marcavalle ( $13^{\circ} 32^{\prime} \mathrm{S}$ Lat, $71^{\circ} 57^{\prime} \mathrm{W}$ Long) is a very low mound, ca. 300 by $200 \mathrm{~m}$, alt. $3314 \mathrm{~m}, 3 \mathrm{~km}$ SE of city of Cuzco, Prov. and Dept. of Cuzco, Peru, Site PCz 6-45 (following Rowe's system of numeration for sites). Samples coll. 1966 and 1968 and subm. by K. L. M. Chávez, Central Michigan Univ., Mt. Pleasant, Michigan (Chavez, 1969; Rowe, 1944; 1956).

\section{P.1560. Lot 4, Trench 3}

$$
2131 \pm 55
$$

181 B.C.

Charcoal, Sample $1 F / 4$, from nat. level ca. 75 to $110 \mathrm{~cm}$ below surface, varying in thickness between 15 and $55 \mathrm{~cm}$. Assoc. sherds are Chanapata-like, similar to Pacalla-mocco; carbonized corn cob fragments and beans assoc. (cf. P-1561) (Rowe, 1944).

\section{P.1561. Lot 4H, Trench 3}

$2096 \pm 51$

Charcoal, Sample $1 \mathrm{~F} / 4 \mathrm{H}$, from lense ca. $2.10 \mathrm{~m}$ below surface $10 \mathrm{~cm}$ thick, lying in large pit terminating in nat. earth, ca. $2.50 \mathrm{~m}$ below surface. Assoc. sherds are Chanapata-like, similar to Pacalla-mocco; carbonized corn cob fragments and beans assoc. (cf. P-1560).

\section{P.1562. Lot 3, 3A, 6, and 12; Trench 2}

Charcoal, combined Samples 1C/3, 1C/3A, 1C/6, and 1C/12, represents one nat. level beginning ca. 20 to $35 \mathrm{~cm}$ below surface, ca. 45 to $75 \mathrm{~cm}$ thick. Assoc. sherds are mostly Marcavalle varieties, including "irridescent" (specular hematite) painted, cream on brown, and dark brown on cream; some polished black grooved; other grooved and incised are also present. Date is derived from same area as is GX-453, 2645 \pm 115 (unpub.) and should be date in this series most comparable to it.

\section{P-1563. Lot 5, Trench 4}

$$
2661 \pm 46
$$
below surface, ca. 10 to $30 \mathrm{~cm}$ thick. Assoc. sherds include varieties such as in Trench 2 (cf. P-1562), but dark brown on cream are nearly absent. Expected date to be younger than that for P-1564, and comparable to date of P-1562.

\section{P-1564. Lot 6, Trench 4}

$2685 \pm 49$ surface and 10 to $30 \mathrm{~cm}$ thick. as in Lot 5,10 varieties as in Lot 5, Trench 4 (cf. P-1563), but black grooved ceramics are nearly absent. Date expected older than P-1563. Comment: $\mathrm{NaOH}$ pretreatment.

\section{P-1566. Lot 9, Trench 1}

$$
\begin{gathered}
2860 \pm 47 \\
910 \text { B.c. }
\end{gathered}
$$

Charcoal, Sample 1B/9, from nat. level ca. $1.20 \mathrm{~m}$ below surface and ca. 2 to $35 \mathrm{~cm}$ thick. Assoc. decorated sherds include Marcavalle incised 
red or brown; painted styles present in Trench 2 and 4 (cf. P-1562-1564) are absent except for a variety of "irridescent" (specular hematite) painted. Fragment of female figurine is also assoc. Expected date older than those for Trenches 2 and 4 (cf. P-1562-1564), on stylistic evidence from ceramics.

\section{P-1567. Lot 8, Trench 1}

$2916 \pm 55$

Charcoal, Sample 1B/8, from nat. level ca. $1 \mathrm{~cm}$ below surface, ca. $20 \mathrm{~cm}$ thick. Assoc. ceramics, including fragment of female figurine, are same as for P-1566. Expected date same or younger than P-1566.

\section{Qaluyu series, Peru}

Qaluyu ( $15^{\circ} 1^{\prime} \mathrm{S}$ Lat, $70^{\circ} 22^{\prime} \mathrm{W}$ Long) is ca. 700 by $210 \mathrm{~m}$ in altiplano, alt. $3390 \mathrm{~m}, 4 \mathrm{~km} \mathrm{~N}$ of Pucara, Prov. of Lampa, Dept. of Puno, Peru, Site PPu 5-2 (following Rowe's system of numeration for sites). Samples coll. 1967 and subm. by K. L. M. Chávez (1969; Rowe, 1956; 1963).

\section{P-1581. Lot 3, Trench 5}

$1949 \pm 52$

Charcoal, Sample 2F/3, from ashy, nat. level containing Pucara culture refuse, beginning $50 \mathrm{~cm}$ below surface, ca. $30 \mathrm{~cm}$ thick, ending in nat. earth. Ceramics include incised outlined red, black, and cream polychrome ware of Pucara style. For dates from Pucara, see: P-152, $2101 \pm$ 108; P-153, $2041 \pm 107 ;$ P-154, $1847 \pm 106 ;$ P-170, $2032 \pm 106$; P-172, $2040 \pm 109$ and P-217, $1960 \pm 90$ (R., 1959, v. 1, p. 57). Comment: $\mathrm{NaOH}$ pretreatment.

\section{P-1582. Lot 4, Trench 1}

Charcoal, Sample 2B/4, from nat. level beginning ca. 55 to $75 \mathrm{~cm}$ below surface and ca. $30 \mathrm{~cm}$ thick. Assoc. Qaluyu ceramics and a few sherds resembling Marcavalle painted varieties such as cream on brown and specular hematite painted (see: P-1562-1564, this list). For 2 previous dates from Qaluyu, see: P-155, $2522 \pm 114$ and P-156, $2962 \pm 120$ (R., 1959 , v. 1, p. 57).

\section{P-1583. Lot 10, Trench 1}

Charcoal, Sample 2B/10, from earth surrounding burial, ca. $1.60 \mathrm{~m}$ below surface. Adult is flexed on left side, shows occipital flattening, body painted with red ochre. No decorated Qaluyu ceramics assoc. Expected date to be same as, or earlier than that for P-1582.

\section{P-1584. Lot 9, Trench 1}

$3045 \pm 56$

Charcoal, Sample 2B/9, from nat. unit beginning $1.60 \mathrm{~m}$ below surface, ca. $40 \mathrm{~cm}$ thick. No decorated Qaluyu sherds were assoc. Expected date older than P-1582. Comment: $\mathrm{NaOH}$ pretreatment. 
P-1585. Lot 16, Trench 1

$3239 \pm 52$

Charcoal, Sample 2B/16, from nat. strat. unit beginning ca. $1.60 \mathrm{~m}$ below surface and ca. $20 \mathrm{~cm}$ max. thickness. No decorated Qalayu sherds in assoc. Date expected to be slightly older or comparable to P-1584.

\section{Pikicallapata series, Peru}

Pikicallepata ( $14^{\circ} 8^{\prime} \mathrm{S}$ Lat, $71^{\circ} 25^{\prime} \mathrm{W}$ Long), is oval-shaped mound ca. 100 by $200 \mathrm{~m}$, alt. ca. $3410 \mathrm{~m}$ overlooking Vilcanota R., between Tinta and Combapata, Prov. of Canchis, Dept. of Cuzco, Peru, Site PCz 5-50 (following Rowe's system of numeration of sites). Samples coll. 1967 and subm. by K. L. M. Chávez (1969; Rowe, 1956).

\section{P.1586. Lot 6, Trench 1}

$2533 \pm 55$

Charcoal, Sample $8 \mathrm{~B} / 6$, from level 1 to $1.20 \mathrm{~m}$ below surface and $30 \mathrm{~cm}$ thick. Assoc. sherds are Chanapata-like in part. Date should be comparable to $\mathrm{N}-89,2520 \pm 150$ and $\mathrm{N}-90,2360 \pm 760$ (R., 1966, v. 8, p. 337). Expected date to be youngest in this series. Comment: $\mathrm{NaOH}$ pretreatment.

\section{P.1587. Lot 9A, Trench 1}

$2705 \pm 66$

Charcoal, Sample 8B/9A, from area of medium-sized stone concentration beginning ca. $1.40 \mathrm{~m}$ below surface, ca. $35 \mathrm{~cm}$ thick, at same level as Sample 8B/9 (cf. P-1588). Should be equivalent to, or slightly younger than P-1588 and P-1589, and younger than remaining samples listed below, this series. Comment: $\mathrm{NaOH}$ pretreatment.

\section{P-1588. Lot 9, Trench 1}

$2797 \pm 58$

Charcoal, Sample $8 \mathrm{~B} / 9$, from level arbitrarily beginning 1.30 to $1.40 \mathrm{~cm}$ below surface, ca. $30 \mathrm{~cm}$ thick, ending in nat. level. Assoc. sherds are Chanapata-like in part.

\section{P-1589. Lot 10, Trench 1}

$$
2627 \pm 48
$$

677 B.C.

Charcoal, Sample 8B/10, from uppermost nat. level of pit beginning ca. $1.55 \mathrm{~m}$ below surface and $30 \mathrm{~cm}$ max. thickness. Assoc. sherds are Chanapata-like in part. Date expected to be roughly equivalent to P-1587 and P-1588, and younger than remaining samples listed below, this series. Comment: $\mathrm{NaOH}$ pretreatment.

\section{F-1.590. Lot 12A, Trench 1}

$$
2894 \pm 51
$$

Charcoal, Sample 8B/12A, from level beginning ca. $1.80 \mathrm{~m}$ below surface, ca. $50 \mathrm{~cm}$ thick. Assoc. sherds are Marcavalle-like in part, such as cream on brown painted and specular hematite painted (cf. Marcavalle series, P-1562-1564, this list). Should be older than samples above, this series. 


\section{P-1591. Lot 15A, Trench 1}

Charcoal, Sample 8B/15A, from level ca. $2.30 \mathrm{~cm}$ below surface, ca. $10 \mathrm{~cm}$ thick. Assoc. sherds are apparently a local style, including a variety of specular hematite painted. Should be older than P-1590 and younger than P-1592.

\section{P-1592. Lot 16, Trench 1}

\section{B.C.}

Charcoal, Sample 8B/16, from necessarily arbitrary level, ca. 2.60 to $2.80 \mathrm{~m}$ below surface, $28 \mathrm{~cm}$ thick. Assoc. sherds are apparently of local style, including a variety of specular hematite painted. Should be the oldest date in this series. Notable, however, culture-bearing levels with further ceramic differences continue below this level to total depth of trench 3.10 to $4.0 \mathrm{~m}$ below surface; these levels should be, stratigraphically and in ceramics, stylistically, older than P-1592.

\section{REFERENCFS}

Andrews, E. E., 1943, The archaeol. of southwestern Campeche: Carnegie Inst. Wash., Pub. 546, Contr. 40, v. 8, p. 11-95.

Arik, R. O., 1937, Les fouilles d'Alaça Hüyük, rapport preliminaire dur les travaux en 1935: Ankara, pubs. de la société d'histoire Turque, 199 p.

Barker, Harold, Burleigh, Richard, and Mecks, Nigel, 1969, British Museum natural radiocarbon measurements VI: Radiocarbon, v. 11, p. 278-294.

Chávez, K. L. M., 1969, Excavations in the Cuzco-Puno area of southern highland Peru: Expedition, v. 11, no. 2, p. 48-51.

Haynes, Jr., C. V., 1966, Radiocarbon samples: chemical removal of plant contamination: Science, v. 151, p. 1391-1392.

Jacobsen, T. W., 1968, Investigations at Porto Cheli-Halieis, 1967: Archaiologikon Deltion, v. 23, p. 144-148.

1969a, Investigations at Porto-Cheli, 1968: Archaiologikon Deltion, v. 24, p. $135-129$.

1969b, The Franchthi cave: Archacol., v. 22, no. 1, p. 4-9.

1969c, Excavations at Porto Cheli and vicinity, preliminary report, II: the Franchthi cave: Hesperia, v. 38, no. 3, p. 348-381.

Kadish, Barbara, 1969, Excavations of prehistoric remains at Aphrodisias, 1968: Am. Jour. Archaeol., v. 73, p. 49-65.

Katzev, M. L., 1969, The Kyrenia wreck: Expedition, v. 11, no. 2, p. 55-59. p. $841-857$. 1970 a, Resurrecting the oldest known Greek ship: Natl. Geog., v. 137, no. 6, 1970 b, A Greek ship is raised: Expedition, v. 12, no. 4, p. 6-14.

Kosay, Hamit and Akok, Mahmut, 1966, Ausgrabungen von Alaça Höyük 1940-48: Ankara, Türk tarih kurumi basimevi, $230 \mathrm{p}$.

Lowdon, J. A., Wilmeth, R., and Blake, Jr., W., 1970, Geol. Survey of Canada radiocarbon dates X: Radiocarbon, v. 12, p. 472-485.

Mellink, M. J., 1969, Archaeol. in Asia Minor: Am. Jour. Archaeol., v. 73, p. 210-211, pl. 57 .

fig. 7

Nanadris, J. G., 1968, Lepinski Vir: Sci. Jour., v. 4, p. 64-70.

Özgüc, Nimet, 1968, New light on the dating of the levels of the Karem of Kanish and of Acem Höyük near Aksaray: Am. Jour. Archacol., v. 72, p. 318-320.

Ralph, E. K., 1955, University of Pennsylvania dates I: Science, v. 121, p. 149-151. p. $45-58$.

Rowe, J. H., 1944, An introduction to the archaeol. of Cuzco: Papers of the Peabody Mus., v. 27, no. 2, p. 1-69.

1956, Archaeol. explor. in southern Peru, 1954-1955: Am. Antiquity, v. 22, no. 2, p. $135-151$. 
Rowe, J. H., 1963, Urban settlements in ancient Peru: Nawpa Pacha, v. 1, p. 1-27. Scholes, V. and Roys, R. L., 1948, The Maya Chontal Indians of Acalan-Tixchel: Norman, Univ. Oklahoma Press, 565 p.

Shroeder A., 1961, Puerco ruin excavation, Petrified Forest, Natl. Monument, Arizona: Plateau, v. 33, no. 4, p. 93-104.

Srejovic, Dragoslav, 1968a, Lepinski Vir 7,000 years ago: Illus. London News, v. 252 no. 6703 , p. $23-25$.

1968b, Lepinski Vir pottery and sculptures: Illus. London News, v. 252, no. 6705 , p. $27-29$.

1969, Lepinski vir: Archaeology, v. 22, no. 1, p. 26-35.

tuckenrath, Jr., Robert and Ralph, E. K., 1965, Univ. of Pennsylvania radiocarbon dates VIII: Radiocarbon, v. 7, p. 187-199.

van Lcon, Maurits and Buccellati, Giorgia, 1969, The 1968 excavation at Korucutepe near Elazig: Turk Arkeol. Dergisi, v. 17, p. 79-82.

Yamasaki, Fumio, Hamada, Tatsuji, and Fujiyama, Chikako, 1966, RIKEN natural radiocarbon measurements II: Radiocarbon, v. 8, p. 324-339. 